\title{
Huumoripoleemikad ja uurijaeetika $^{1}$
}

\section{Liisi Laineste}

Teesid: Ehkki huumor on üldiselt tuntud lõbustava ja ohutu žanrina, võib selle mitmekihiline olemus anda tulemuseks tähendusi, mis ei olnud kavatsuslikud. Mitmetimõistetava ja seetõttu tundliku materjali avalikustamine andmebaasides või uurimistöö osana peaks toimuma äärmise ettevaatlikkusega. Võimalikke probleeme tuleks osata ette näha ja ennetada, õppides seda tegema varasemate juhtumite põhjal. Kui uurija jätab tähelepanuta tõiga, et arhiveeritud (huumori) tekste on võimalik mitmeti tõlgendada ning mõni tõlgendus võib olla vaenulik mõne sotsiaalse institutsiooni või isegi ühiskonna suhtes tervikuna, võib ootamatult lahvatada arvamuste kokkupõrge.

Käesolevas artiklis vaadeldakse huumorit arhiivikontekstis ja sellest väljaspool, visandatakse naljade ja neid ümbritseva ühiskondliku reaalsuse suhteid ning peatutakse pikemalt huumori politiseeritud funktsioonil. Arhiiviväliste kontekstidena võib nimetada publitseerimise konteksti (naljakogumikud, mis koostati arhiivimaterjali põhjal), pedagoogilist konteksti (õpik, mis naljakogumikele viitas), meedia konteksti (selleteemaline diskussioon meedias), uurimiskonteksti jm. Uurimus käsitleb meediareaktsiooni, mis järgnes venevastaste naljade avastamisele põhikooli õpiku lisamaterjalis 2007. aastal. Selle juhtumiga tegelemise käigus avastasid ajakirjanikud Eesti Kirjandusmuuseumi serveris asuva anekdootide andmebaasi, mis sisaldas muuhulgas ka rassistlikuna tõlgendatavaid nalju. Need seigad valmistasid ette edasist avalikku diskussiooni uurijaeetika, huumori definitsioonide ja staatuse ning natsionalismi ja rassismi teemadel.

Huumori ja solvangu piiril balansseerivate naljatamisjuhtumite kirjeldamine aitab seletada huumoripoliitikat: millised naljapärimuse aspektid osutuvad huumori üle peetavates avalikes aruteludes olulisteks, kuidas peaks uurija suhestuma huumori eetilisuse kohta käibivate tavaarusaamadega, miks naljad üldse eksisteerivad ja kas on võimalik püüda likvideerida nende tekkepõhjusi ning mis juhtub, kui erinevate kogukondade huumoritõlgendused lähevad omavahel vastuollu.

Märksõnad: etniline huumor, folklooriandmebaasid, huumor, rassism, uurijaeetika 


\section{Sissejuhatus}

Huumor on olemuselt mitmetähenduslik. Selle peamiseks mehhanismiks on kahe näiliselt vastuolulise mõtteraamistiku ühitamisel tekkinud äratundmismoment ja üllatus (põhimõiste on siinkohal skriptide ühitamatus (incongruity) vt Raskin 1985; Attardo 1994 jt; vt ka sellekohast diskussiooni nt Krikmann 2007; Oring 1992). Mitmetähenduslikkust võib pidada samaaegselt huumori väärtuseks ja puuduseks; see on huumori põhimehhanism, kuid samas ka peamine põhjus, miks nali alati ei õnnestu. Kui nalja auditoorium ei näe (või ei soovi näha) vastandlikest ideedest tulenevat kokkupõrget ning tajub sõnumit ühetähenduslikult solvavana, on nali äpardunud (vt ka Hay 2001; Norrick \& Chiaro 2009). Vahel on nalja mitte-mõistmine seotud erinevate väärtushinnangutega. Väärtushinnangud hea/halb, normaalne/ebanormaalne vms kaasnevad vaikimisi kasutatavate mõtteraamistikega, kusjuures positiivne hinnang omistatakse rühmale, millega samastutakse, ning negatiivne neile, kes on erinevad ning seega naeruväärsed, so rühmale, kellele vastandutakse (see võib, aga ei pruugi kattuda nalja objektiga). Enamasti on puänt see, mis juhatab sisse ebatavalise lähenemise või lahenduse nalja alguses püstitatud probleemile, kuid sageli on kuulajal vaja juba enne puändini jõudmist häälestuda õigele lainele ja siseneda mitteheauskse, nn non-bona-fide kommunikatsiooni maailma, kus reaalsus on nihestunud ning eeldused ei vasta päriselus kehtivatele. Seega nõuab huumor publikult paindlikku, mängulist ja loovat lähenemist ning tavaliste väärtushinnangute ja kooliteadmiste ajutist kõrvaleheitmist. Erinev publik on nõus oma hinnangutest loobuma erineval määral, olenevalt tema puhul kehtivatest kultuurilistest ja sotsiaalsetest normidest. Mõne silmis on tabuteemaks religioon, eriti selle karikatuurne kujutamine (nt poleemika Muhamedi kujutavate karikatuuride üle aastal 2006); teistel on raske näha midagi naljakat näiteks seksistlikes anekdootides. Kuigi nalja potentsiaalne naljakus või agressiivsus ei peitu ainult anekdoodis ja kuulajaskonna eelistustes vaid ka selle esitamise kontekstis (näiteks on suur vahe, kas rassistlikke nalju räägib sihtrühm enda kohta või esitab nalja kõrvalseisja, vt Billig 2005a: 31), võib mingil määral ka ainult nalja teksti põhjal oletada, kui suur on võimalus, et tekst, mis balansseerib lubatu ja lubamatu piiril, võib haavata mingit osa auditooriumist.

Kui nalju edastataks üksnes suuliselt, võiks nalja rääkija üsna suure kindlusega ennustada publiku reaktsiooni, sest tegu on vahetu suhtlussituatsiooniga. Kuid huumor võib jõuda auditooriumini ka mitmel muul moel, nagu siinsestki analüüsist näha: ajakirjanduse vahendusel (nt Muhamedi kujutavad karikatuurid ilmusid Taani päevalehes Jyllands-Posten); filmides (nt Sacha Baron Coheni mängufilm "Borat") ja mõne sellise allika kaudu, kust koomikat 
üldiselt ei oodata (nt kooliõpikud jmt). Nende kanalite publik pole kaugeltki nii homogeenne kui suulise huumoriesituse piiratud kuulajaskond. Eriti tänapäeval, mil suur osa igapäevasuhtlusest toimub internetis, võidakse ajalehes avaldatut või filmis kujutatut reprodutseerida, parodeerida, edasi arendada arvututel viisidel. Niiviisi leiab potentsiaalselt solvav materjal (kas siis töödelduna või originaalkujul) tee ennenägematult suure globaalse auditooriumini ja võib põhjustada tõsiseid, reaalsete tagajärgedega konflikte. Lisaks sellele mängib nalja mõistmisel olulist rolli ka ajaline mõõde: naljaraamatud, mis on naljakad väljaandmise ajal, ei pruugi seda enam olla kümne aasta möödudes.

Kui algselt huumorina mõeldud tekst või pilt jõuab ebasobiva auditooriumini, reageerib publik sellele erinevalt: kulmukortsutusest avalike, vahel isegi inimohvreid nõudvate pahameeleavaldusteni. Konflikt, mis võib olla vägagi terav, toob enamasti endaga kaasa avaliku arutelu huumori mõiste üle: mis üldse on huumor, mille üle on lubatud nalja teha ja mille üle mitte, kui suur väärtus on antud kultuuris sõnavabadusel, kas huumorit saab pidada funktsionaalseks nähtuseks jms (vt ka Lewis 2008). Siit on vaid väike samm anekdootide või karikatuuride politiseerumiseni: neid hakatakse kasutama tõendusmaterjalina selle kohta, et nende levitaja toetab ja propageerib rassistlikke arvamusi. Politiseerumist mõjutab ka uskumus, et huumor mõjutab auditooriumi hoiakuid; seega arvatakse, et agressiivne nali on ühiskonnale ohtlik ning seda saab kasutada argumendina poliitilises diskussioonis. Mõned uurimused (nt Ford 2000 ; Ford \& Ferguson 2004) on tõestanud, et rassistlikud naljad võivad tõepoolest tugevdada olemasolevaid negatiivseid stereotüüpe nalja objekti kohta ja toovad need ka argisuhtluses esiplaanile, kuid teisalt on see seos äärmiselt mitmetahuline ning sõltub suurest hulgast muutujatest (nt kes on rääkija ja kes kuulub publiku hulka, kas kuulajad on stereotüüpidega tuttavad, kui usutavalt neid esitatakse jne), mida on eksperimentaalsetes uurimustes raske kontrollida (Martin 2008: 16).

Naljade politiseerumine on viimase aja globaalsete huumoriskandaalide siduv ühisnimetaja. Nii Muhamedi karikatuuride, Borati tegelaskuju kui ka siinses artiklis käsitletava materjali puhul jääb silma nalja agressiivseks pidanud inimeste väide, et selline huumor on tegelikult halvastivarjatud vaenulikkus teise rahvuse/riigi/rühma vastu, ning nõue, et selliseid tekste tuleks tsenseerida. Samas on nähtav ka püüe keerata huumor nalja rääkija vastu ning kasutada seda argumendina arvamussõjas hea ja halva huumori, sõnavabaduse jm teemadel.

Selline strateegia ei pruugi viia soovitud tulemuseni. Kui huumori sihtmärk üritab tõestada, et naljas sisalduvad stereotüübid ei vasta tõele ning väidab, et see annab kinnitust nalja rääkijate piiratud, stereotüüpsest ja ksenofoobsest mõttemallist, võidakse teda süüdistada huumorimeele puudumises, huu- 
morimeel aga on eelkõige Lääne ühiskonnas kõrgelt väärtustatud omadus. Huumorimeeleta inimesed võivad oma jäiga hoiaku tõttu muutuda kergesti naeruväärseks (Billig 2005b: 194).

Käesoleva artikli eesmärk on kirjeldada ja analüüsida avalikku diskussiooni, mille vallandas 2007. aasta sügisel toimunud skandaal, kui põhikooli kirjandustundide õppematerjali autorit süüdistati rassistlike naljade propageerimises. Sellega seoses kerkisid päevakorrale huumori erinevad definitsioonid, huumori staatus ühiskonnas ning natsionalismi/rassismi teema. Arutelu puudutas ka uurijaeetikat, rahvaluule avaldamise ja populariseerimise problemaatikat, enesetsenseerimist ja üldisemat arhiivipoliitikat, sest selle käigus sattus kriitika alla Eesti Kirjandusmuuseumi veebipõhine anekdoodiandmebaas, kus leidub mõningaid potentsiaalselt agressiivseid nalju. Võrdleva perspektiivi saamiseks analüüsitakse meediareaktsiooni nendele sündmustele (veebis avaldatud artikleid ning nende kommentaare) kõrvuti teiste varasemate rahvusvaheliste huumoriskandaalidega, s.o Muhamedi karikatuuride ja Borati tegelaskuju ümber tekkinud poleemikaga. Huumori ja solvangu piiril balansseerivate naljatamisjuhtumite kirjeldamine aitab seletada huumoripoliitikat: millised naljapärimuse aspektid osutuvad huumori üle peetavates avalikes aruteludes olulisteks, millised eetika-alased dilemmad võivad huumoriuurijatele ette tulla ning mis juhtub, kui inimeste huumoritõlgendused ja arusaamad lähevad omavahel vastuollu.

\section{Poleemika: anekdoodid õppematerjalis ja andmebaasis}

Oktoobris 2007 kaebas üks lapsevanem teadus- ja haridusministeeriumile, et eesti keele õpik vene koolidele soovitab põhikoolilastele lisalugemiseks rassistliku sisuga materjali. Naljakogusid, millele kaebus viitas, oli kolm: Banaanil on nohu: Valik koolinalju ja muud (Kalmre 1996), Neeger päevitab: Maailma rahvad eesti laste naljades (Tuisk 1996) ja Elevant külmkapis: Kimbuke keerdküsimusi koolilaste suust (Voolaid 1998). Lastenaljade kogumikud pärinesid kogu Eestit hõlmanud koolipärimuse kogumise võistluselt aastast 1992, seega koosnesid need naljadest (keerdküsimustest ja anekdootidest), mis olid tuntud koolilaste seas 1990. aastate alguses. Näiteks sisaldasid need järgmisi nalju:

Miks kannavad venelased õlgkübarat?

Sest sõnnik kaetakse ikka õlgedega kinni.

Mis vahe on neegril ja sibulal?

Sibulat lõigates tuleb vesi silma. 
Et kaebusele vastamisega viivitati ja lapsevanem ei saanud kahe nädala jooksul vastust, pöördus ta ajakirjanduse poole. Esmalt võttis teema üles venekeelne meedia. Oktoobri keskel avaldati selleteemaline artikkel ajalehes MKEstonija, mis nimetas õppematerjali eesti kooliõpikute koostajate jämedaks veaks, mille tulemusel tekivad ja tugevnevad vastuvõtlikus eas lastel rahvusstereotüübid ja mis õhutab etnilist vimma eestlaste ja venelaste vahel. Kuigi lapsevanem väitis, et tema ei soovi tekitada skandaali, vaid tahab lapsevanema ja õpetajana osutada võimalikele kitsaskohtadele ühiskonnas, sai teema venekeelsetes ajalehtedes ruttu võimendatud käsitluse. Nii väitis üks artikkel (Gusev 2007), et eesti kooliõpikud õpetavad eesti lapsi venelaste üle naerma; vastukajana sellele väljendasid murelikud venekeelsed kodanikud toimuva üle pahameelt.

Käesolev artikkel kirjeldab eestikeelse meedia reaktsiooni sellisele probleemipüstitusele. Venekeelse meedia vastukaja nii artiklites kui ka nende kommentaarides jääb selle artikli piiridest välja. Lähemalt analüüsime kaheksat artiklit, mis avaldati online-meedia saitidel (Delfi, Eesti Ekspress, Eesti Päevaleht, Õhtuleht, Postimees, Reporter) 17. oktoobrist 1. novembrini 2007, ning vaatleme ka nende uudiste veebikommentaare (kokku 407 postitust).

\begin{tabular}{|l|l|l|c|}
\hline & Allikas & Artikli pealkiri & Kuupäev \\
\hline A1 & postimees.ee & $\begin{array}{l}\text { Lapsevanema arvates soovitab õpik } \\
\text { lugeda rassistlikke naljakogumikke }\end{array}$ & 17.10 \\
\hline A2 & postimees.ee & $\begin{array}{l}\text { Õpiku autor eitab rassistlike naljade } \\
\text { soovitamist }\end{array}$ & 17.10 \\
\hline A3 & delfi.ee & Kuidas hoida neegrid oma aiast eemal & 25.10 \\
\hline A4 & reporter.ee & $\begin{array}{l}\text { Venemaa kasutab eestlaste mustamiseks } \\
\text { Eesti koolilaste anekdoote }\end{array}$ & 25.10 \\
\hline A5 & postimees.ee & $\begin{array}{l}\text { Lukas vabandas rassistlike } \\
\text { naljakogumike pärast }\end{array}$ & 31.10 \\
\hline A6 & delfi.ee & $\begin{array}{l}\text { Tõnis Lukas vabandas rassistlike } \\
\text { naljakogumike pärast }\end{array}$ & 01.11 \\
\hline A7 & epl.ee & $\begin{array}{l}\text { Muuseum võitleb rassismi levitamise } \\
\text { sü̈distustega }\end{array}$ & 01.11 \\
\hline A8 & delfi.ee & $\begin{array}{l}\text { Neegrinaljad peidetakse tavakasutaja } \\
\text { eest? }\end{array}$ & \\
\hline
\end{tabular}

Tabel 1. Artiklid veebiajakirjandusest, mille sisu ja kommentaare siinses analüüsis kasutati. 
Esiteks teen ülevaate artiklite peamistest seisukohtadest, et kirjeldada ametlikku diskursust, mida esindavad poliitikud ja ajakirjanikud, teiseks kirjeldan mitteametlikku diskursust ja selle põhifookust veebikommentaarides. Mõlemal juhul kategoriseeriti materjali kvalitatiivse andmeanalüüsi programmiga QDA Miner, ning saadud põhikategooriatest lähtuvalt on vormistatud ka artikli teemapüstitus ja arutelu.

\section{Ametlik ja mitteametlik diskursus online-meedias}

Kaheksa vaatlusaluse artikli pealkirjad (vt tabel 1) illustreerivad hästi neis kaitstavaid seisukohti ja diskussiooni käigus toimunud arenguid. Esimesed kaks kajastavad kahte põhilist argumenti. Esimene ("Lapsevanema arvates soovitab õpik lugeda rassistlikke naljakogumikke") kinnitab, et süüdistused haridusministeeriumi aadressil on tõsiseltvõetavad (kuigi need esindavad lapsevanema, mitte üldsuse arvamust). Seevastu teise uudise pealkiri (“Õpiku autor eitab rassistlike naljade soovitamist”) esitab vastuargumendi, näidates probleemi õpiku koostaja poolelt, kes ei näe antud kogumikes midagi keelatut. Diskussioon tekib niisiis algusest peale selle ümber, kas õpikus üleüldse leidus soovitus lugeda rassistlikke nalju, ja teiseks, kas viidatud naljad olid rassistlikud või mitte. Ajakirjanike seisukoht neis uudisnuppudes on pigem süüdistav, väidetakse, et selliste naljade avaldamine või nendele viitamine on mõtlematu ja sobimatu. Seda toetab ka viis, kuidas artiklites kirjeldatakse õpiku autorit, nt "Nahkuri [õpiku autor - autori märkus] sõnul pole ta seda kogumikku päris rida-realt läbi lugenud, vaid sirvinud” (A2). Samasugune pealiskaudsuse kuvand jääb lugejal ministeeriumi ametnikust, kes sel teemal sõna võttis: "[---] kodune ülesanne puudutas vaid raamatut "Banaanil on nohu", selgitab oma vastuses ametnik" (A2). Esimesele kahele järgnenud artiklid on kriitilisemad, sest see "ebameeldiv ja häbiväärne lugu" (Infopartisan, 20. oktoober 2007) jõuab laiema auditooriumi ette. Ka ajakirjanikud mõistavad, et teema õhutab diskussiooni ja paneb inimesed kaasa mõtlema, sellelt pinnalt avaldatakse artikkel "Kuidas hoida neegrid oma aiast eemal". See pealkiri parafraseerib keerdküsimust, mille artikli autor Krister Kivi leidis Eesti Kirjandusmuuseumi serveris asuvast anekdoodiotsingust. Samal ajal on aktiivsed ka poliitkorrektsuse vastased (nt "Venemaa kasutab eestlaste mustamiseks Eesti koolilaste anekdoote”). Veelgi elavam arutelu järgneb haridusminister Tõnis Lukase vabandusele venelaste ees, mis ühelt poolt paneb punkti ametlikule mõttevahetusele, teisalt aga annab hoogu paralleelsele teemale, mis vaeb Eesti Kirjandusmuuseumi anekdoodikogu eetilisust ("Muuseum võitleb rassismi levitamise süüdistustega" ja "Neegrinaljad peidetakse tavakasutaja 
eest?"). Need artiklid tekitasid mõttevahetust selle üle, mis on huumor ning milline on piir huumori ja solvangu vahel.

Meediadiskursus võib olla väga mõjuvõimas; see dramatiseerib toimunut ja haarab inimesed kaasa, mõjutades emotsioone ja hoiakuid. Mida provotseerivam on teema ja laiem selle kõlapind, seda aktiivsemalt kommenteerivad teemat erinevate arvamusrühmade esindajad ning seda rohkem tuleb ette konflikte. Meedia üritab omakorda esitada probleeme sellistena, et need kõnetaksid (vahel ka vaidlustaksid) kehtivat võimustruktuuri ja selle ideoloogilisi seisukohti (Smith \& Saltzman 1995). Nii tõusevad iga teema juures esile just valulikud küsimused, millele auditoorium reageerib viha ja vastuoluliste seisukohavõttudega. Antud juhtumi puhul keskendus diskussioon venelaste olukorrale Eestis ja integratsiooni võimalikkusele, mis on olnud pärast 1990. aastaid üks kohalike poliitikute ja kodanike lemmikteemasid.

Siin vaadeldavad kaheksa veebimeedias avaldatud artiklit väljendavad enamasti poliitkorrektset seisukohta: kui ühiskonnas on kalduvus rassismile, tuleks seda juba eos takistada, st ennetamine on parim strateegia (seda võib nimetada enesekriitiliseks diskursuseks, vt ka Vihalemm \& Timmi 2007). Anekdoote nimetatakse otseselt rassistlikeks, ja selline lähenemine ei jäta ruumi mõistete üle vaidlemiseks. Ajakirjanike sõnavalik väljendab seda juba diskussiooni varajases faasis: "ministeeriumi poolt kinnitatud õpik soovitab 12- kuni 13-aastastele lastele raamatuid, mis sisaldavad rassistlikke nalju [---]" (A1) - seda, kas naljad olid rassistlikud või kõik neist seda siiski polnud, ei peeta siinkohal üldse vajalikuks kahtluse alla panna.

Seevastu edasistes artiklites see seisukoht taandub, asemele tuleb avaram lähenemine, mis lubab arutleda huumori olemuse ja sõnavabaduse teemadel: “----] kui suur osa inimestest näeb siin probleemi, siis järelikult on probleem olemas [---]" (A5). Kuigi vajadus rassistlikke anekdoote keelata on pandud küsimärgi alla, rõhutatakse siiski, et juhul, kui rassism esineb (või inimesed midagi rassismina tajuvad), tuleb potentsiaalselt ohtlikke materjale tsenseerida.

Edasi arutletakse poliitkorrektsuses peituvate ohtude üle, mis ka kommentaarides selgelt esile tuleb (vt peatükki mitteametliku diskursuse kohta). Oma meedias avaldatud ametlikku vabandust kommenteerides ütleb haridusminister Tõnis Lukas, et Venemaa propagandamasin otsib kohti, kus saaks näidata Eestile näpuga, või nagu ajakirjanik tema mõtet parafraseerib: "Lukase sõnul ei hakata aastate jooksul laste poolt koostatud anekdoodikogumikke selle kampaania pärast tuleriidal põletama." (A6). Artiklites tõstetakse esiplaanile huumori ja anekdootide seost reaalsusega - mil määral need tegelikkust peegeldavad ja kui tõepärane see peegeldus on. Arutelu jooksul hakatakse arvamust avaldama ka selle üle, kui mõistlik on anekdootide olemasolu põhjal väita midagi terve rahvuse kohta. See seostub huumoriteoorias kaua päevakorral olnud küsimu- 
sega anekdootide seosest tegeliku rühmadevahelise konfliktiga (vt ka Davies 2002; 2007). Mõnes vaadeldud uudises kinnitatakse, et anekdoodid pole kindlasti rassismiga otseselt seotud, ning seega on süüdistused alusetud: "Nali ja folkloor pole tegelikkuse peegel. Näiteks naljad neegritest on rahvusvahelised ja nende sagedase esinemise põhjuseks pole eestlaste seas leviv rassism." (Eda Kalmre kommentaar juhtumile, A8).

\section{Mitteametlik: artiklite veebikommentaarid}

Ametliku ja mitteametliku diskursuse ehk veebimeedias avaldatud artiklite ja kommentaarides nähtavate arvamusavalduste vahel on terav vastuolu. Põhierinevus on selles, et viimaste seas domineerib arvamus tsensuuri kahjulikkusest demokraatlikus ühiskonnas. Kommenteerijad väljendavalt julgemalt arvamust, et nalju ei tohi mitte mingil juhul keelata, olgu need rassistlikud või mitte. Eriti aktiveerusid kommentaatorid pärast haridusministri vabandavat (kuigi mitmetimõistetavat) sõnavõttu, milles peegeldus ühelt poolt poliitiku arusaam teema tundlikkusest ja teisalt mõistmine, et liiga range poliitkorrektsuse järgimine viib absurdini. Loomulikult puudutasid kommentaarid ka venelaste integreerumist Eestis, rõhutades, et täielikult assimileerunud vähemus peaks omaks võtma ka kohalikud naljad ning et anekdootide peale solvumine näitab vaid muulaste soovimatust integreeruda. Toodi välja seda, et lõhe Eestis elavate venelaste ja eestlaste vahel suureneb veelgi, kui naerdakse erinevate asjade üle, samas kui "normaalne" oleks huumorit kergelt võtta: "Põhjendamatu foobia. Kui eestlaste kohta nalja tehakse, siis naerab ka eestlane kaasa. Milles probleem? Inimesed hakkavad vist manduma (amerikaniseeruma), et huumorit huumoriga võtta enam ei suuda." (A2, Humorist 17.10.2007 19:30) ja "Pole need ju midagi muud kui lihtsad naljakesed. Inimesed, kes siit rassismi välja loevad, on ise rassistid. Normaalne inimene, olgu siis eestlane või venelane, saab naljast aru ja naerab." (A2 jne 18.10.2007 00:47). Nii mõnedki kommentaatorid lähenesid teemale huumori, iroonia ja sarkasmiga ("Ma vabandan petka ja tshapai ees, samuti kõikide tshuktshide, venelaste-sakslaste-ameeriklaste, rebase, karu ja jänese, neegrite ja juutide... ja üldse kõigi ees kellest anekdoote olen rääkinud või nende üle naernud..." (A3, Sin 25.10.2007 23:17)), teised tsiteerisid anekdoote, mis neil artiklites avaldatuga seoses meelde olid tulnud ("Inglane, sakslane ja eestlane on üksikul saarel. Püüavad kuldkala, see ütleb: Laske lahti, täidan igal ühe soovi. Inglane soovib tagasi Londonisse ja ongi läinud, sakslane Berliini ja on kah läinud. Eestlane küsib: "Kas ma tervitada saaks?"” (A3, fashistõ-pidirastõ to tibla raisk 25.10.2007 23:11)). Mõned anekdoodid olid otseselt rassistlikud: "Kuidas nimetada neegrit, kellel on Harvardi haridus? - 
Neeger" (A5, misvahetsealon, 31.10.2007 18:32). Selline tendents näitas, et rassistlikest anekdootidest rääkimine toob solvavad anekdoodid avalikkuse ette, ning siis ei viidata enam ainult ajakirjanduses tsiteerituile, vaid tuuakse lisaks nii uusi kui ka vanu näiteid samast kategooriast. Naljad inspireerivad uusi nalju nii veebisuhtluses kui ka mujal, ning see töötab vastu n-ö ametlikule eesmärgile: osutada sellele, mis peaks olema ühiskonnas keelatud. Peale selle, et nalju defineeriti kahjutu fenomenina, mida ei tohiks tsenseerida, leidus ka neid, kes arvasid vastupidist. Nende meelest on anekdoodid normaalne osa elust, olgugi et need on vahel kohatud, ning miski ei tohiks anda põhjust neid tsenseerida: "Naabrid ja ka muud on alati üksteist aasinud ja töganud. Pealegi ei keela keegi neegritel valge kohta nalju teha või siin avaldada. Kõige lihtsam on keelata." (A8, värvuk, 01.11 .2007 04:46). Väga tihti nihkub diskussioon rahvusküsimusele ja eestlaste-venelaste suhetele: "Venelased katsugu ikka omal maal hakkama saada, aga millegipärast oleme seal populaarsed, viisa mittesaamise puhul nälgitakse ja naljade puhul kuulutatakse või sõda." (A3, Lemme Krimm 25.10.2007 22:34). Nagu internetisuhtluse puhul tavaline, on nii mõnigi kommentaar salvavalt terav, isegi agressiivne. Leimi objektiks on eelkõige venelased (aga ka mustanahalised), keda kujutatakse grupina, kel puudub huumorimeel ja kes on meist kardinaalselt erinevad; nad ei kuulu läänelike rahvaste hulka. Otsest solvangutki võib kohata: "See, et tible [tibla] on loll, ei ole anekdoot. See on TÕDE ise.” (A5, halenaljakas, 31.10.2007 18:32), ning ka siin näeme hinnangut anekdootide tõeväärtuse kohta.

Samas leidus kommentaare, mis pidasid tsensuuri vajalikuks ning poliitkorrektsuse järgimist ajastu normiks, millega ka Eesti peaks tsiviliseeritud riigina arvestama. Ka nende rolli, olgugi marginaalsemat, ei saa alahinnata: sageli sai diskussioon hoo sisse alles pärast seda, kui rassistlike või sõnavabadust iga hinna eest pooldavate postitajate sekka ilmus poliitkorrektsuse eestkõneleja. Selle järel hakati vastandumise kaudu väljendama oma arvamust õigest ja valest, eetilisest ja ebaeetilisest huumorist. Oluline on ka see, et vastandlikud seisukohad kaugenesid diskussiooni käigus veelgi, ning polariseerumise tagajärjel muutus sõnasõda üha tulisemaks (vt ka Mackie \& Cooper 1984). Poliitkorrektsust toetavad kommentaarid võisid olla üsna sarkastilised: "Masendav koht see Eesti! Rassistlik, fashistlik, seksistlik, homo- ja ksenofoobne. Ainult valge mees saab Eestis rahulikult elada - kõik ülejäänud, kes sellesse kategooriasse ei mahu (naised, homod, mustanahalised, muulased) mürgitatakse vihkamise kibeda sapiga." (A3, Londonlane - 25.10.2007 11:24:08).

Üldiselt võib öelda, et enamasti kuulusid kommentaatorid kahte suuremasse rühma: ühed uskusid, et rassism on (anekdootides) olemas ja seda peaks kindlasti tsenseerima; teised arvasid, et rassismi pole ning midagi ei tohiks tsenseerida ka siis, kui keegi osutab sellele kui rassismile. Kindlasti suure- 
nes diskussiooni jooksul (etniliste) anekdootide postitamise sagedus. Suurenes ka Eesti Kirjandusmuuseumi anekdoodiotsingu veebilehe külastatavus. Inimesed üritasid kommentaariumides meenutada varemkuuldud poliitiliselt ebakorrektseid anekdoote. Sel moel võeti kriitika alla mitte ainult liiga tõsine suhtumine huumorisse, vaid ka liialdatud poliitkorrektsus ja poliitkorrektsete inimeste oskamatus huumorit hinnata. Mõned naljad pilkasid euroametnikke, kelle ülesandeks on jälgida Euroliidu liikmesriikide ksenofoobsustaset: "Mitu europolitrukki on vaja, et lampi lakke keerata? - Arv ei oma tähtsust, sest puudub eurodirektiiv." (A5, :), 31.10.2007 18:59).

\section{Diskussioon}

\section{Reaktsioonid huumorile}

Äpardunud huumor (Bell 2009; vt ka Laineste 2010, 2012, 2013) on huumoriuurimise valdkonnas üsna hiljutine teema. Selle kirjeldamine aitab uurijal määratleda huumori olemust ja ennustada või seletada võimalikke negatiivseid reaktsioone. Hinnang sellele, kas tegu on rünnaku, solvangu või meelelahutusega ja sellele tuginev reaktsioon oleneb auditooriumi mõistmisvõimest ning valmidusest kaasa mängida. Jennifer Hay (2001: 67) huumori mõistmise mudel osutab kolmele etapile, kus huumor võib äparduda. Ta väidab, et nalja positiivseks hindamiseks on vaja tunda ära, et tegu oli huumoriga, seejärel olla võimeline tekstist aru saama semantilisel tasandil, kolmandaks tuleb huumorit tunnistada ning heaks kiita kaasanaermise või muu positiivse reaktsiooniga. Viimasel tasandil mängib eriti olulist rolli auditooriumi ja nalja rääkija ühine kultuuritaust, mille pinnalt teineteisemõistmine algab. Kui ühes kultuuris levinud (nalja)tekst jõuab ilma kontekstita ja lisaselgitusteta teise kultuuriruumi (mis internetiajastul sageli juhtub), on huumori ebaõnnestumise tõenäosus üsna suur. Võib oletada, et internetihuumori puhul esineb paradoksaalne olukord, mil võimalus saavutada auditooriumi heakskiitu (võrreldes silmast silma suhtlusega) on ühtaegu nii suurem kui ka väiksem: positiivset hinnangut naljadele toetab globaliseerumine, kultuurinormide parem tundmine, identiteetide paljusus; negatiivset aga internetikasutajate anonüümsus, adressaadi ennustamatus ning tekstide jõudmine publikuni, keda naljarääkija polnud silmas pidanud. Viimast on Michael Billig (2005a) kirjeldanud kui mittenaeru (un-laughter), defineerides seda kui auditooriumi teadlikku ja rõhutatult negatiivset seisukohavõttu nalja ja selle rääkija suhtes.

Suhtumine huumorisse on sajandite vältel olnud erinev. Mitte alati pole huumorit võetud kui positiivset nähtust, mis parendab elukvaliteeti ja tugevdab sõprust ja rühmaidentiteeti. Üleolekuteooria (superiority theory) väitis 
alates Aristotelesest ja Hobbesist, et huumor tekib rõõmust, et ollakse teistest parem, ning positiivse "naer on terviseks" seisukoha jaoks polnud selles teoorias kohta. Ka žanriliselt on huumor väga mitmekesine. Lühikesed naljalood anekdoodi vormis muutusid populaarseks koos trükisõna levikuga ning said normiks 17. sajandil (Dekker 2001, vt ka Wickberg 1998, kes väidab, et anekdoot hakkas laiemalt levima 19. sajandi tööstusrevolutsiooni käigus elutempo üldise kiirenemise tõttu). Samas idamaades, näiteks Hiinas ja Jaapanis, ei tuntud anekdooti meile teadaoleval kujul kuni viimase ajani. Sealne huumoritraditsioon arenes teises suunas, hõlmates muuhulgas humoorikaid luuletusi ja rituaalset naermist, kuid mitte puändiga lühikesi naljalugusid, mida tuntakse läänelikes kultuurides. Huumorile hakati rohkem väärtust ja tähelepanu (sh akadeemilist) omistama alles 20. sajandi alguses. Eri kultuurides hinnatakse huumorit praegugi erinevalt, vaatamata humoorikate tekstide ja piltide globaalsele levikule internetis.

Kultuurid, mille vahel tekib maitse-eelistusi puudutav konflikt, ei pruugi olla tegelikkuses kuigi erinevad: konflikti põhjustab pigem laialt levinud uskumus, et anekdoot peegeldab tegelikkust ning rassistlik anekdoot väljendab rääkija tegelikke hoiakuid, et nalja rääkija tahtis nalja kaudu väljendada oma negatiivset arvamust nalja objekti kohta. Etniliste naljade suhtes valitseb eriti kõrge tundlikkus. Nende jagamist peetakse üldiselt taktitundetuks ja halva maitse väljenduseks. Kuid kui vaadata huumorikonflikte nalja rääkija seisukohast, tähendab mittenaermine ühtlasi negatiivset hinnangut nalja rääkija huumorimeele suhtes. Seda süüdistust ei andestata kergekäeliselt; mittenaermisele reageeritakse sageli irooniliselt. Naerul on jõud defineerida ja säilitada kultuuride ja rühmade vahelisi piire. See on üks olulisi aspekte vastanduse meie-nemad loomises ning identiteediküsimustes laiemalt.

\section{Võrdlus varasemate huumoripoleemikatega}

Siinses materjalis tuleb selgelt esile huumori võime põhjustada diskussioone eetika ja kultuuridevahelise suhtluse üle - õpikust avastatud anekdoodid ja lugemiseks soovitatud naljakogud tekitasid avaliku arutelu, mis toimus nii ametlikul kui ka mitteametlikul tasandil (esimesel vastandusid Eesti ja Vene poliitikute nägemused heast ja sobilikust huumorist, teisel aga inimeste arvamused kommentaariumides). Selle tulemusel (taas)sõnastati lubatu ja lubamatu, hea ja halva maitse piirid, arutleti huumori olemuse ja sõnavabaduse üle. Võrdluses samalaadsete varasemate juhtumitega näeme, kuidas diskussioonid huumori üle on globaliseeruvas ühiskonnas varemgi esile kerkinud. Nende puhul mängib olulist rolli tänapäeva multimeedia, vahendades seisukohti ja kujundades arvamusi. 
Enim tähelepanu on pälvinud kaks suuremat huumori baasil tekkinud poleemikat, mille algatasid karikatuurid prohvet Muhamedist ja film "Borat". Siinset juhtumit käsitlemegi järgnevalt nende kahe poleemika valguses. Karikatuurid prohvet Muhamedist avaldati ajalehes JyllandsPosten 30. septembril 2005. aastal; need koosnesid 12 pildist, mida kohalikud taanlastest islamiusulised pidasid halva maitse tipuks. Tegelik konflikt puhkes aga alles veebruaris 2006, kui info karikatuuridest jõudis laiema auditooriumi ette, ja islamiusulised erinevates maailma nurkades protesteerisid nende avaldamise vastu, boikoteerides Taani tooteid ja rünnates Taani saatkondi. Film "Borat" (täispealkirjaga "Borat: Cultural learnings of America to make benefit glorious nation of Kazakhstan") jõudis kinodesse novembris 2006. See on komöödia kasahhist, kelle seiklusi Ameerika Ühendriikides saadab ebaõnn. Filmis naeruvääristatakse ühtaegu kasahhide primitiivsust ja ameeriklaste ksenofoobiat. Linateos võeti vastu vastuoluliste tundmustega, näiteks ilmus ajalehe New York Times lisana Kasahstani valitsuse finantseeritud neljaleheline infoleht (vt lähemat Fletcher 2006), milles lükati ümber filmis loodud pilti Kasahstanist (diskrimineerimine, prostitutsioon, majanduslik mahajäämus jms).

Nimetatud poleemikate paiskamisel rahvusvahelisse meediasse laienes drastiliselt nende auditoorium, mis omakorda tingis vastasleeri mobiliseerumise. Need, kes nägid Muhamedi karikatuurides ja Borati filmis nuripidist huumorit, osutasid sealsele "huumorile" kui agressiivsele rünnakule ning demoniseerisid sellega muidu süütu meelelahutusena võetava kultuurilise fenomeni. Teoreetikud nägid selles kultuuride või isegi tsivilisatsioonide konflikti (nt Harding 2006). Arutledes huumori äpardumise põhjuste üle, jõuti lõpuks välja sõnavabaduse ja tsensuuri teemani (Lewis 2008).

Kolmel juhtumil leidub mitmeid ühisjooni. Huumorikonfliktis osalenud osapooled olid ebavõrdse kaalu ja suurusega: Taani väikelinna päevaleht $J y l$ lands-Posten oli vastasseisus terve islamimaailmaga; filmitegija Sacha Baron Cohen ja tema tiim suure osaga ameeriklastest, juutidest ja kasahhidest ning Eesti riik opositsioonis Venemaaga. Väidetav ründaja oli rünnatavast seega oluliselt väiksema kaaluga nii kohalikus kui ka globaalses plaanis. Oluline ühisjoon on seegi, et igas konfliktis kasutati huumorit emotsionaalselt efektiivse argumendina propagandasõjas. Solvatud leeri poliitiline identiteet oli sarnane: nad kõik esindasid rahvusvahelises poliitikas mittedemokraatlikku jõudu. Neis riikides piiratakse inimõigusi ja sõnavabadust (nt riigi kontroll massimeedia üle Venemaal; naise positsioon islamimaades jms). Lisaks sellele rebiti konflikti käigus huumor välja selle esialgsest (eelkõige meelelahutustlikust) kontekstist ja rõhutati seda kui ilmset näidet nalja rääkijate agressiivsusest nalja sihtmärgi vastu. Huumorit mõista aitava olulise lisainfo kadumist soodustas 
rahvusvahelise meedia sekkumine, massilises tõlkimises ja levitamises läks kaotsi ajalooline, kultuuriline, aga ka vahetu sotsiaalne kontekst. Uueks globaalseks aruteluteemaks sai huumori väidetavalt agressiivne ja vihaõhutav olemus, millele omakorda tekkis tugev vastuseis naljast arusaajate seas. Niisiis tegutsesid kaks polariseerunud kogukonda: ühed, kes nägid avaldatud tekstides ja piltides vaid huumorit ning nõudsid, et nalja tuleb võtta naljaga, ning teised, kelle silmis oli tekkinud diskussioon tõsiseltvõetav võimalus astuda välja enesekaitseks. Ühed nõudsid sõnavabadust, teised aga avalikku vabandamist ja solvajate karistamist. Vastasseisus polariseerusid leerid veelgi; varasemalt tajutud erinevused (näiteks Euroopa ja islamimaade) vahel suurenesid ning vastukaaluks tugevnes mõlema leeri sisemine sidusus. Polariseerumise põhjuseid ei tuleks selles kontekstis otsida mitte ainult konkreetsest huumoritekstist vaid ka väärtuste ja hoiakute süsteemist, mis reaktsioone mõjutasid: mittenaermises tajuti ohtu läänelikule mõttemallile ja eluviisile, sh sõnavabadusele, naermises aga otsest rünnakut nende vastu, keda läänemaailm peab "võõrasteks".

Mõlemad pooled on valmis reaalseks füüsiliseks rünnakuks, et oma seisukohta kaitsta. Globaalse konflikti puhul tuleb näha ohtu üldisele julgeolekule, olgugi et tegu on "kõigest huumoriga". Kuigi ainult Muhamedi karikatuuride puhul toimus kahe leeri vahel reaalseid kokkupõrkeid (selle konflikti mõjuala oli ka suurim), võib tulevikuski ette tulla olukordi, kus meedia provotseerib vastasseisu hetkeni, mil konflikt väljub kontrolli alt ning eskaleerub ettearvamatult suureks. Solvatute silmis pole tegu huumori, vaid tõsise solvanguga, mis nõuab sama tõsist vastureaktsiooni.

Tundub, et mittenaermine ei ole pikas perspektiivis tulus reaktsioon, sest kuigi see tugevdab mõneks ajaks siseringi identiteeti, kinnitab see laiema auditooriumi negatiivset arvamust nalja objektist ja/või rühmast, kes otsustab mitte kaasa naerda: mittenaermist tajutakse naeruväärsena, see näitab nõrkust ja rumalust. ${ }^{2}$ Tõsiste argumentidega huumori vastu astumine ei näi veenev ning annab alust edasisele pilale.

Lisaks tavameediale ja selle kommentaaridele käsitleti tsensuuri ka akadeemilistes ringkondades (Lewis 2006; Lewis 2008). Siingi oli põhiteemaks huumori definitsioon ja selle roll globaliseeruvas maailmas nimetatud konfliktide näitel. Eriti rõhutati ajakirjanduse rolli poleemika õhutamisel ja avalikkuse kaasamisel. Need näited ilmestasid ka jätkuvat arutelu uurijaeetikast. Huumori funktsionalistlikud käsitlused (vt Kuipers 2008: 364-368) lähtuvad eeldusest, et huumorit ei mõjuta üksnes reaalsus. See seos toimib ka vastupidi, st huumor võib mõjutada reaalsust: aidata kaasa poliitiliste režiimide lõpule, kinnistada soolisi stereotüüpe, ajendada hoiakute muutumist jms. Niisiis võib sellise lähenemise kohaselt juhuslikult kuuldud rassistlik anekdoot tekitada sallivust vastavate vaadete suhtes (vt selleteemalist diskussiooni Lewis 1997). 
Viimasel aastakümnel, kuigi mõnel määral ka varem, põhjendati sellega poliitkorrektsuse vajalikkust. Kuigi empiiriliste uuringute tulemused ei toeta täielikult funktsionalistlikku lähenemist huumorile (vt Martin 2007: 142-143), pooldavad tavaarusaamad huumori toimimisest ikka veel sellist seost. Akadeemilise huumoriuurimise seisukohalt tähendab see pidevat diskussiooni, millest ja kuidas tohib artikleid kirjutada, et see kedagi ei haavaks. Uurijad on sageli sunnitud rakendama enesetsensuuri ning piirduma oma artiklites vaid argumentatsiooni seisukohalt hädavajalike näidetega, vältides selliseid, mis võiksid potentsiaalset lugejat solvata. Kuigi teadlastele ei tohiks seada uurimisalaseid tabusid, piirab see ometi uuritavate teemade valikut. Michael Billig (2005a) on uurijaeetika teemat käsitledes rõhutanud, et kuigi akadeemiliste artiklite lugejaskond on piiratud, ei tea teadlane artiklit kirjutades siiski täpselt seda, kes on tulevane lugeja ning milline on tema taluvuslävi. Lockyer \& Pickering osutavad huumori ja agressiivsuse olulistele küsimustele (2005: 4-5), tõdedes, et potentsiaalselt haavavad naljanäited akadeemilises tekstis võivad küll taastoota naljades sisalduvaid stereotüüpe, kuid samas ei ole võimalik kirjutada oma uurimusi ilma näidetele viitamata. Uurija peab olema eriti ettevaatlik, kui ta räägib teemadel, mis võivad toetada või levitada negatiivseid ja ühiskonnavaenulikke käitumismalle. Folkloristika puhul lisandub dilemma anekdootide ja muu tundliku materjali kogumisest ja talletamisest andmebaasides. Viimased aastad Eesti Kirjandusmuuseumi folkloristika osakonnas on näidanud, et online-andmebaaside tulekuga kaasneb mitmeid ohte, mida varem ei tuntud. Ligipääs andmebaasidele on suurem; neid saab kasutada iga huviline. Osa andmebaase pakub lisamaterjali õpetajatele ja õpilastele, teised nende kõrval võivad aga sisaldada lugejat solvavat või allikat diskrediteerivat materjali. Nagu mitmetitõlgendatava õppematerjali puhul, väljendus ka andmebaaside sisu käsitlevas diskussioonis, mis toimus paralleelselt õpiku-teemalise aruteluga, kaks vastandlikku arvamust, mida esindasid ühelt poolt ametlik diskursus veebiajakirjanduses ja teisalt mitteametlik diskursus artiklite kommentaarides. Esimeses hoiatati, et “[a]jakirjanduses kajastatud süüdistused, et eesti folklooris leidub rassismi, võivad muuta tavakasutajatele ligipääsu internetis olevale folklooriandmebaasile raskemaks" (A7). Kuid ametlik poliitkorrektne soovitus piirata ligipääsu andmebaasidele parooliga või tsenseerida seal avaldatavat materjali leidis terava vastuseisu kommentaarides, mille meeleolu väljendab hästi järgmine sõnavõtt: "Peitke nii palju kui tahate, lähme üleüldse sotsialismiaega tagasi selle varjamise jamaga. Meil on jälle kelle ees lömitada." (A7, folkloor elab rahvasuus, 01.11.2007 05:05). Selle avaliku arvamusvahetuse tulemusel kasvas andmebaasi külastatavus hüppeliselt mitmekordseks. 


\section{Kokkuvõte}

Ksenofoobilist tõlgendust võimaldavate anekdootide avaldamine kirjandustundide õppematerjali lisana tekitas rahvusvahelist poleemikat, milles vastandusid ametlik ja mitteametlik diskursus. Võrdluses varasemate rahvusvaheliste huumoripoleemikatega nägime, et arvamuste ja maailmavaadete vastandumine on sellise tundliku materjali puhul tavaline - eriti globaliseeruvas maailmas, kus auditoorium on määramatu ning selle eelistused ja reaktsioonid ennustamatud. Anekdootidest rääkimine ja näidete toomine ei vähenda nende hulka, vaid tekitab seoseid pigem juurde. Kirjeldatud juhtumi näitel näeme, et meedia, mis ametlikus diskursuses üritas avaliku arutelu kaudu manitseda inimesi poliitkorrektsusele, taastootis samal ajal sobimatut huumorit. Liigne tähelepanu osutus provokatsiooniks, mis tõi rassismi juurde, mitte ei piiranud seda. Tagaplaanile jäi ka õpiku koostajate endi seisukoht ning õppematerjalide algne kontekst: folkloori sotsiaalsetest ja lähiajaloolistest aspektidest, sh sihtrühmatundlikust huumori käsitlemisest, ei räägita pikemalt enam ei siin vaadeldud artiklites ega nende kommentaarides.

Ka akadeemilises probleemikäsitluses võib rassistliku ja muul moel tundliku huumorimaterjali puhul tekkida poleemika uurijaeetikast. Uurijad peavad olema aina rohkem teadlikud sellest, et nende uurimust (või isegi selleks kogutud materjali) võidakse pidada solvavaks ja ebaeetiliseks. Kui probleem on jõudnud laiema auditooriumi ette, pole uurijal enam sõnaõigust, sest teema on väljunud algse teksti autori kontrolli alt; samuti pole ruumi läbirääkimisteks "hea" ja "halva" maitse piiridest, sest vajadus nii välise kui sisemise tsensuuri järele on tõusnud koos poliitkorrektsuse nõude tugevnemisega. Kas me peaksime andmebaase kasutajatele sulgema, allikate nimed salastama ja näidetest artiklites loobuma? Lihtsaid ja üheseid vastuseid neile küsimustele pole. Kuid võimalikke ohte tuleb tähele panna. Seejuures on oluline arvestada kõikide osapooltega (poliitikud, meedia, laiem publik, uurijad, jne), kellel kõigil võib olla erinev seisukoht antud probleemi suhtes. Hiljutised huumoripoleemikad on akadeemilise kogukonna, sealhulgas folkloristide tähelepanu neile ohtudele suunanud, osutades ka võimalikele tulevastele probleemidele.

\section{Kommentaarid}

1 Artikkel valmis ETF8149 ja IUT22-05 toel.

2 Tuleks rõhutada, et nimetatud skandaalide ühisnimetajaks oli ebaproportsionaalne ja valulik reaktsioon huumoritekstile. Võimalik, et see kirjeldab Billigi terminist täpsemalt toimunud skandaali tagamaid, sest mittenaer viitab passiivsele, kuigi negatiivsele suhtumisele, samas oli tauniv hinnang näiteks õppematerjalis kasutatud anekdootidele või Muhamedi karikatuuridele kõike muud kui passiivne. 


\section{Kirjandus}

Attardo, Salvatore 1994. Linguistic Theories of Humor. Berlin \& New York: Walter de Gruyter.

Bell, Nancy 2009. Impolite Responses to Failed Humor. Norrick, Neal R. \& Chiaro, Delia (toim). Humor in Interaction. Amsterdam \& Philadelphia, PA: John Benjamins Publishing Company, lk 143-163 (doi: 10.1075/pbns.182.07bel).

Billig, Michael 2005a. Comic racism and violence. Lockyer, Sharon \& Pickering, Michael (toim). Beyond a joke: The limits of humour. Basingstoke: Palgrave Macmillan, lk 25-44.

Billig, Michael 2005b. Laughter and ridicule. Towards a social critique of humour. London \& Thousand Oaks: Sage Publications.

Davies, Christie 2002. The mirth of nations. New Brunswick \& London: Transaction Publishers.

Davies, Christie 2007. Humour and protest: Jokes under communism. International Review of Social History 52, lk 291-305 (doi: 10.1017/S0020859007003252).

Dekker, Rudolf 2001. Humour in Dutch culture of the golden age. Basingstoke: Palgrave (doi: 10.1057/9780230509474).

Fletcher, Phyllis. 2006. Kasakhstan Embassy responds to Borat. NPR, October 16 (http:// www.npr.org/templates/story/story.php?storyId=6276973 - 16. september 2014).

Ford, Thomas E. 2000. Effects of sexist humor on tolerance of sexist events. Personality and Social Psychology Bulletin 26, lk 1094-1107.

Ford, Thomas E. \& Ferguson, Mark A. 2004. Some sociology of humour: The joke. International Social Science Review 63, lk 431-446.

Gusev, Aleksei 2007. Uchebniki uchat estonskikh detei smeiat'sia nad russkimi (Õpikud õpetavad eesti lapsi venelaste üle naerma). Utro, October 18 (http://www.utro. ru/ articles/2007/10/18/688371.shtml - 16. september 2014).

Harding, Gareth 2006. Analysis: A cartoon spat a culture clash? The Washington Times, February 15 (http://www.lebanonwire.com/0602MN/06021601UP.asp - 16. september 2014).

Hay, Jennifer 2001. The pragmatics of humor support. Humor: International Journal of Humor Research 14, Nr 1, lk 55-82 (doi: 10.1515/humr.14.1.55).

Infopartisan, 20. oktoober 2007 (http://infopartisan.blogspot.com/2007/10/ebameeldivja-hbivrne-lugu.html - 16. september 2014).

Kalmre, Eda (koost) 1996. Banaanil on nohu: Valik koolinalju ja muud. Tallinn: Koolibri.

Krikmann, Arvo 2007. Contemporary Linguistic Theories of Humour. Folklore: Electronic Journal of Folklore 33, lk 27-57 (doi: 10.7592/FEJF2006.33.kriku).

Kuipers, Giselinde 2008. The sociology of humor. Victor Raskin (toim). The Primer of Humor Research. Berlin/New York: Mouton de Gruyter, lk 361-398 (doi: 10.1515/9783110198492.361). 
Laineste, Liisi 2010. Äpardunud huumor internetikommentaarides. Keel ja Kirjandus 8-9, lk 655-670 (http://keeljakirjandus.eki.ee/Laineste\%20655-670.pdf-16. september 2014).

Laineste, Liisi 2012. Verbal expressions of aggressiveness in Estonian Internet. Liisi Laineste \& Dorota Brzozowska \& Władysław Chłopicki (toim). Estonia and Poland. Creativity and tradition in cultural communication. Tartu: ELM Scholarly Press, lk 205-220 (doi:10.7592/EP.1.laineste.liisi).

Laineste, Liisi 2013. Funny or aggressive? Failed humour in Internet comments. Folklore: Electronic Journal of Folklore 53, lk 29-46 (doi: 10.7592/FEJF2013.53.laineste).

Lewis, Paul 1997. Debate: Humor and political correctness. Humor: International Journal of Humor Research 10 (4), lk 453-513.

Lewis, Paul 2006. Cracking up: American humor in a time of conflict. Chicago: University of Chicago Press.

Lewis, Paul \& Davies, Christie \& Kuipers, Griselinde \& Martin, Rod A. \& Oring, Elliot \& Raskin, Victor (toim) 2008. The Muhammad cartoons and humor research: A collection of essays. Humor: International Journal of Humor Research 21 (1), lk 1-46 (doi: 10.1515/HUMOR.2008.001).

Lockyer, Sharon \& Pickering, Michael (toim) 2005. Beyond a Joke: The Limits of Humour. Basingstoke \& New York: Palgrave Macmillan.

Mackie, Diane \& Cooper, Joel 1984. Attitude polarisation: Effects of group membership. Journal of Personality and Social Psychology 46, lk 575-585 (doi: 10.1037/00223514.46.3.575).

Martin, Rod A. 2008. The psychology of humor. An integrative approach. Burlington: Elsevier Academic Press.

Norrick, Neal R. \& Chiaro, Delia (toim) 2009. Humor in interaction. Amsterdam \& Philadelphia, PA: John Benjamin's Publishing Company (doi: 10.1075/pbns.182).

Oring, Elliott 1992. Jokes and their relations. Lexington: University Press of Kentucky.

Raskin, Victor 1985. Semantic mechanisms of humor. Dordrecht: D. Reidel Publishing Company.

Smith, Moira \& Saltzman, Rachelle H. 1995. Introduction to tastelessness. Journal of Folklore Research 32 (2), lk 85-99.

Tuisk, Astrid (koost) 1996. Neeger päevitab: Maailma rahvad Eesti laste naljades. Tallinn: Koolibri.

Vihalemm, Triin \& Timmi, Mailis 2007. Rassism eesti trükimeedias. Rassism ja ksenofoobia Eestis. Tallinn: Justiitsministeerium (http://www.just.ee/orb.aw/class=file/ action=preview/id=54339/Rassism+ja+ksenofoobia_18.05.2011.pdf - ei ole enam kättesaadav).

Voolaid, Piret (koost) 1998. Elevant külmkapis: Kimbuke keerdküsimusi koolilaste suust. Tallinn: Koolibri.

Wickberg, Daniel 1998. The senses of Humor: Self and Laughter in Modern America. Ithaca: Cornell University Press. 


\section{Allikad}

A1 = Rudi, Hanneli. Lapsevanema arvates soovitab õpik lugeda rassistlikke naljakogumikke. Postimees.ee, Eesti uudised 17. oktoober 2007 (http://www.postimees. ee/1716341/lapsevanema-arvates-soovitab-opik-lugeda-rassistlikke-naljakogumikke 16. september 2014).

A2 = Rudi, Hanneli. Õpiku autor eitab rassistlike naljade soovitamist. Postimees.ee, Eesti uudised 17. oktoober 2007 (http://www.postimees.ee/1716359/opiku-autor-eitabrassistlike-naljade-soovitamist - 16. september 2014).

A3 = Kuidas hoida neegrid oma aiast eemal. Eesti Ekspress 25. oktoober 2007 (http://www.delfi.ee/news/paevauudised/eesti/kuidas-hoida-neegrid-oma-aiasteemal.d?id=17250894 - 16. september 2014).

A4 = Henno, Erik. Reporter.ee: Venemaa kasutab eestlaste mustamiseks Eesti koolilaste anekdoote. Postimees.ee, Eesti uudised, 25. oktoober 2007 (http://w3.ee/openarticle. php?id=638280\&lang=est -16 . september 2014).

A5 = Tiks, Oliver. Lukas vabandas rassistlike naljakogumike pärast. Postimees.ee, Eesti uudised, 31. oktoober 2007 (http://www.postimees.ee/1721579/lukas-vabandasrassistlike-naljakogumike-parast - 16. september 2014).

A6 = Tõnis Lukas vabandas rassistlike naljakogumike pärast. Delfi.ee, 31. oktoober 2007 (http://www.delfi.ee/news/paevauudised/eesti/lukas-vabandas-rassistlike-anekdootideparast.d?id=17307550 - 16. september 2014).

A7 = Leitmaa, Dannar. Muuseum võitleb rassismi levitamise süüdistustega. Eesti Päevaleht, 1. november 2007 (http://epl.delfi.ee/news/eesti/muuseum-voitleb-rassismilevitamise-suudistustega.d?id=51107018 - 16. september 2014).

A8 = Neegrinaljad peidetakse tavakasutaja eest? Eesti Päevaleht online, Delfi.ee, 1. november 2007 (http://www.delfi.ee/news/paevauudised/eesti/neegrinaljad-peidetaksetavakasutaja-eest.d?id=17311118 -16 . september 2014 )

\section{Summary}

\section{Humour Polemics and Research Ethics}

\section{Liisi Laineste}

Keywords: ethnic humour, folklore databases, humour, racism, research ethics

The link between jokes and social reality is visible in the way that jokes adapt to different socio-political contexts by dealing with the most salient issues of such contexts. This article casts light on another facet of the relationship of jokes and their social context. Ideas about jokes are influenced by their social context, being continuously reformulated by social change or political manipulation. The case study, brought to illustrate the point further, analyses media discourses that address the issues of and relationships between taste and sense of humour, mostly focusing on the reception of ethnic jokes. The different standpoints visible in the media, both in official and unofficial discourse, reflect ideas about the content and functions of jokelore, characterising jokes either as an essentially racist or as a funny (i.e., harmless) genre. 